\title{
Biochemical and Molecular Variations of Guaiacol Peroxidase and Total Phenols in Bacterial Wilt Pathogenesis of Solanum melongena
}

\section{Prakasha A and Umesha S}

Department of Studies in Biotechnology, University of Mysore, Manasagangotri, Mysore, Karnataka, India

*Corresponding author: Umesha S, Department of Studies in Biotechnology, University of Mysore, Manasagangotri, Mysore, Karnataka, India, Tel: +91 821 2419884, E-mail: su@appbot.uni-mysore.ac.in, pmumesh@gmail.com

Rec date: Jul 19, 2016; Acc date: Sep 12, 2016; Pub date: Sep 15, 2016

Copyright: (C) 2016 Avinash P, et al. This is an open-access article distributed under the terms of the Creative Commons Attribution License, which permits unrestricted use, distribution, and reproduction in any medium, provided the original author and source are credited.

\begin{abstract}
Plants respond to bacterial pathogen attack by activating various defense responses, which are associated with the accumulation of several factors like defense-related enzymes and inhibitors which serve to prevent pathogen infection. The present study focused on the role of the defense-related enzyme and gene expression of Guaiacol preroxidase and Total phenol content in imparting activities was analyzed by selecting three different eggplant cultivars against bacterial wilt pathogen Ralstonia solanacearum. The temporal pattern of induction of these enzymes showed $(42.72 \mathrm{U})$ maximum activity at $21 \mathrm{~h}$ after the pathogen inoculation (hpi) in resistant cultivars. The expressions of defense genes increased 5.5 folds in resistant eggplant cultivars after pathogen inoculation. The total phenol content increased significantly $(\mathrm{P}<0.05)$ in resistant cultivars upon pathogen inoculation compared to susceptible and highly susceptible cultivars. The biochemical and molecular markers provided an insight to understand the first line of defense responses in eggplant cultivars upon inoculation with the pathogen.
\end{abstract}

Keywords: Ralstonia solanacearum; Guaiacol peroxidase; Bacterial wilt; Eggplant; QRT-PCR

\section{Introduction}

Brinjal (Solanum melongena L.), also known as Aubergine or the Eggplant, it is a commonly cultivated vegetable in countries like China, India, Egypt and Iran. Some of the common diseases affecting the production of eggplant are Damping off, Phomopsis blight, Verticillum wilt, Bacterial wilt, Cercospora leaf spot, and Little leaf of eggplant. One of the most common and devastating disease that affects the production of eggplant is the Bacterial wilt caused by Ralstonia solanacearum. It is gram-negative, rod-shaped, strictly aerobic bacterium which is primarily a soil-borne and waterborne pathogen [1]. It infects host plants from their roots, infected from damaged wounds formed by lateral root emergence or by root damage caused by soil borne organisms. $R$. solanacearum infect the roots or stems, they colonize the plant through the xylem in the vascular bundles. Wilting of the whole plant may follow rapidly if environmental conditions are favorable for the pathogen. Plant-to-plant infection can occur when bacteria shed from infected roots move to roots of nearby healthy plants. Therefore, the management of this disease is very difficult [2-4].

When a pathogen invades a plant, it defends itself by means of active and passive defense mechanisms. The passive or pre-existing defense mechanisms include structural barriers which prevent the colonization of the tissue. The active defense mechanisms involve the generation of hypersensitive response (HR), the production of phytoalexins and pathogenesis-related proteins, the production of reactive oxygen species (ROS) and reactive nitrogen species (RNS) (termed as oxidative bursts), lignifications, and reinforcement of cell wall structural proteins and deposition of callose. The efficacy of these defense responses together with anti-oxidant responses often determines whether the plants are susceptible or resistant to pathogen infection.
Guaiacol preroxidase (GPOD: EC.1.11.1.7) are prevalent enzymes that participate in a fundamental role of plant defense mechanisms. GPOD is a heme containing glycosylated proteins that catalyze the oxido-reduction of aromatic electron donor such as guaiacol and pyragallol at the cost of hydrogen peroxidase. GPOD enzymes structurally composites of four conserved disulfide bridges and contain two structural $\mathrm{Ca}^{2+}$ ions interconnected [5]. Higher plants possess a number of different GPOD isoenzymes in plant tissues localized in vacuoles, cytosol and cell wall [6,7]. GPOD also called as GPX, POX are widely accepted as stress "enzyme" GPOD can function as effective quencher of reactive intermediary forms of Oxygen and peroxy radicals under plant pathogen interactions. GPOD have been implicated in many significant mechanisms was revived, In conclusion several reports explained GPOD play a fundamental roles such as lignification of cell wall, oxidation of hydroxy-cinnamyl alcohol into free radical intermediates, degradation of IAA, regulation of plant cell elongation, biosynthesis of ethylene, wound healing, and polysaccharide cross linking [8].

Various plants defense mechanisms were studied against abiotic and biotic stresses conditions of the environment by induce the activity of GPOD. The increase in GPOD activity during resistance in different hosts against different pathogens has been demonstrated. Southerton and Deverall [9] reported that increases in GPOD activity were greater during the expression of resistance in wheat against the leaf-rust fungus than in susceptible plants. Increase in the GPOD activity was observed during the interaction between rice and Xanthomonas oryzae pv. Oryzae [10-12] and between cotton and Xanthomonas axonopodis pv. Malvacearum [13]. Guaiacol peroxidase might also play an important role in Cassava bacterial blight caused by Xanthomonas axonopodis pv. Manihotis [14,15]. Ikegawa, et al. [16] showed that the activity of ionically bound cell wall peroxidases was significantly higher in incompatible interactions of oat with Puccinia coronata $f$. sp. avenae than in a compatible one. Mohammadi and Kazemi [17] reported that there is an increased GPOD activity in heads of both 
resistant and susceptible wheat cultivars during various developmental stages following the inoculation with Fusarium graminearum. Peroxidase activity was increased in resistant pearl millet cultivars infected with Sclerospora graminicola than in susceptible cultivars [18]. Delannoy, et al. [19] suggests that cotton peroxidases may have various functions in the defense response to Xanthomonas infections. Mlickova et al. [20] showed that increased GPOD activity occurred in two stages in Lycopersicon species resistant to Oidium neolycopersici. Silva et al. [21] revealed the increased GPOD activity in relation to host cell wall lignifications in coffee resistance to orange rust.

Up-regulation of peroxidases (membrane-bound class III peroxidases) in maize seedlings stress responses activated by methyl jasmonate and salicylic acid pathways reviled that, GPOD not only function in abiotic stress but also in pathogen response [22]. Mandal et al. [23] undertook to investigate the biochemical aspects of oxidative burst, anti-oxidative mechanism and cell wall reinforcement as initial defense responses of two tomato cultivars viz., Arka Meghali (susceptible) and BT-10 (resistant) against the devastating bacterial wilt pathogen $R$. solanacearum. The tomato variety BT-10 has been identified as resistant to $R$. solanacearum due to rapid increase in GPOD activity. Meanwhile in our previous reports Vanitha and Umesha [24] analyzed Pre-treatment of tomato plants with $P$. fluorescens triggered the increased preroxidase. Plant growth promoting rhizobacteria (PGPR) microorganisms were assessing their capacity to prime rice seedlings against stress challenge (salt and Xanthomonas campestris infection). GPOD was significantly primed by both strains $24 \mathrm{~h}$ after stress challenge was reported by Cristobal et al. [25]. The involvement of GPOD in defense mechanism of $R$. solanacearum infection in eggplant remains unclear. In order to accomplish this void information, the present study was undertaken to analyze role of guaiacol peroxidase and total phenol content in host resistance of bacterial wilt.

\section{Material and Methods}

\section{Bacterial source and growth conditions}

Ralstonia solanacearum was isolated from soil source in the agricultural fields of Karnataka state, India. The bacteria were isolated and maintained on a semi-selective Kelman's TTC medium [26]. The isolated pathogen was confirmed by biochemical/physiological, pathogenicity tests. Biochemical characterization of $R$. solanacearum was performed based on biochemical tests: Gram staining, $\mathrm{KOH}$ solubility, starch hydrolysis test [27], lipase activity, Kovacs' oxidase test [28], gelatin hydrolysis and oxidative/fermentative metabolism of glucose. Strains were classified to biovar using a variation in physiological test developed by Hayward [29] in a test tube, the determination of biovars of $R$. solanacearum is based on utilization of Hayward medium (Dextrose, lactose, dulcitol, or D-mannitol) along with D-ribose and meso-inosital were used to separate biovars $2 \mathrm{~A}$ and 2B by inoculating $20 \mu \mathrm{l}$ of $R$. solanacearum culture at concentration of $(1 \times 108 \mathrm{cfu} \mathrm{ml}-)$ and tubes were incubated at $28^{\circ} \mathrm{C}$ for 15 days. Uncultured tubes were kept as control. Molecular identification methods were performed by PCR amplification using 16S rRNA [30]. The glycerol stocks of bacterial cultures were prepared and submitted to the Stock Collection Centre (Department of Studies in Biotechnology, University of Mysore, Mysore, India) and were used for all further inoculations.

\section{Chemicals and collection of seed samples}

All chemicals used in sample preparation were of analytical grade. All authentic standards and primers were procured from SigmaAldrich Chemical Co. Ltd (Bangalore, India). Molecular biology chemicals were procured from Genetix, Bangalore, India. Seeds of eggplant cultivar Arka Shirish (resistant to bacterial wilt) were procured from National Seed Corporation, Bangalore, India. MEBH-11 (susceptible) and Chaman 363 (highly susceptible) cultivars seeds obtained from Annadatha Kendra and private seed traders respectively of Mysore, India. They were disinfected by surface sterilization with $3 \%(\mathrm{v} / \mathrm{v})$ sodium hypochlorite solution for $5 \mathrm{~min}$ and washed with sterile distilled water thrice.

\section{Ralstonia solanacearum inoculation to eggplants}

The seeds were sown in $9 \mathrm{~cm}$ diameter plastic pots under greenhouse conditions. Eggplant cultivars (Arka Shirish, MEBH-11 and Chaman 363) were subjected to screening against bacterial wilt disease by following standard procedures of Trans-Kersten et al. [31]. Briefly, seedlings were raised from all the cultivars of eggplant in $9 \mathrm{~cm}$ diameter plastic pots containing a mixture of sterilized soil, sand, coir pith and farmyard manure in the ratio of 2:1:1:1. For each cultivar, 16 plants in three replicates were maintained under greenhouse conditions at the temperature of $28 \pm 2^{\circ} \mathrm{C}$ and the experiments were repeated thrice. The $R$. solanacearum culture grown on the Kelman's TTC medium was suspended in distilled water and centrifuged at $12000 \mathrm{rpm}$ for $10 \mathrm{~min}$ and the pellet obtained was re-suspended in sterile distilled water. The density of cell suspension was adjusted to $1 \mathrm{x} 108 \mathrm{cfu} / \mathrm{ml}$ using spectrophotometer (Beckman Coulter, California, USA). The bacterial suspension $(15 \mathrm{ml})$ was poured directly near the root system of 24-day-old eggplant seedlings. Control plants were mock inoculated using sterile distilled water. The seedlings were harvested at time intervals of $0,3,6,9,12,15,18,24$, up to $120 \mathrm{~h}$, that is with an interval of $3 \mathrm{~h}$ each after pathogen inoculation (HPI). The roots were washed in tap water and immediately frozen by storing in deep freezer at $-80^{\circ} \mathrm{C}$ for further analysis. The experiments consisted of three replicates and were repeated three times. Eggplant seedlings were examined carefully for the typical bacterial wilt symptoms such as stunting, wilting, vascular browning and often rapid death from the day of inoculation and up to 45 days.

\section{Enzyme assay and native-PAGE analysis of GPOD}

Guaiacol peroxidase (EC.1.11.1.7): Guaiacol peroxidase assay was performed by following the standard procedure specified by Naveen, et al. [32]. The reaction mixture consisted of $2.9 \mathrm{ml}$ of substrate buffer (125 ml of $0.05 \mathrm{M}$ Guaiacol, $153 \mathrm{ml}$ of $30 \% \mathrm{H}_{2} \mathrm{O}_{2}$ [v/v] in $50 \mathrm{ml}$ of 0.1 $\mathrm{M}$ potassium phosphate buffer [pH 7.0]) and $0.1 \mathrm{ml}$ of enzyme extract. Increase in absorbance was $(470 \mathrm{~nm})$ recorded for $1 \mathrm{~min}$ and expressed as the change in the absorbance at $470 \mathrm{~nm} \mathrm{~min} / \mathrm{mg} /$ protein. GPOD activity was expressed as units of enzyme activity (U). Units were calculated using a molar extinction coefficient of 26.6 units for tetra guaiacol. The concentration of protein in the enzyme extracts was determined by standard procedure of Bradford (1976), using BSA (Sigma, USA) as standard.

The isoforms profile of GPOD was examined by Native-PAGE (Native polyacrylamide gel electrophoresis) following the standard protocol of Laemmli [33]. GPOD enzyme extracted (100 mg protein) from resistant, susceptible and highly susceptible eggplant cultivars at $18 \mathrm{~h}$. Three cultivars inoculated with pathogen and controls were 
loaded on top of $8 \%(\mathrm{w} / \mathrm{v})$ polyacrylamide gels in a vertical gel electrophoresis (Tarsons, Bangalore, India). Electrophoresis gels were run in a voltage of $50 \mathrm{~V}$ initially for $1 \mathrm{~h}$ and further complete electrophoresis was performed in $100 \mathrm{~V}$. The electrophoresis was run with Tris-base buffer (6.0 g Tris-base, $14.4 \mathrm{~g}$ glycine dissolved in $1 \mathrm{~L}$ of distilled water). After electrophoresis, GPOD isoforms were stained with $100 \mathrm{mg}$ benzidine/ $\mathrm{ml}$ of absolute alcohol by soaking the gels in staining solution and made up to $40 \mathrm{ml}$ using distilled water. Clear solution was obtained by adding $100 \mu \mathrm{l}$ of glacial acetic acid, $\mathrm{H}_{2} \mathrm{O}_{2}(50$ $\mu \mathrm{l}$ ) was added to the filtered staining solution at the end and gels were incubated in the solution till bands appear and gels were documented using Geldoc 1000 System-PC (Bio-Rad, Gurgaon, India).

\section{RT-PCR studies}

Total RNA was extracted from seedlings of R (Arka Shirish), S (MEBH-11) and HS (Chaman 363) eggplant cultivars by grinding them into powder in pre-chilled mortar and pestle with liquid nitrogen. The powder $(100 \mathrm{mg})$ was homogenized and centrifuged at 12, $000 \mathrm{rpm}$ for $10 \mathrm{~min}$ in $1 \mathrm{ml}$ of TRIzol@ reagent (Sigma, Bangalore, India). The supernatant was again centrifuged in $200 \mu \mathrm{l}$ of chloroform and treated with $1 \mathrm{ml}$ of isoamyl alcohol and finally RNA was precipitated with ethanol [34]. cDNA was synthesized by reverse transcription reaction by following the manufacturer's instruction using cDNA synthesis kit (Thermo Scientific, Bangalore, India).

The primers used in the present studies were designed using the complete cDNA sequences of GPOD sequences reported in the GenBank. Sequences were retrieved from the nucleotide database of NCBI of solanaceae crops (tomato, potato, eggplant). The sequences were aligned using CLUSTAL W software and specific sets of primers were designed (Table 1) using Primer 3 software; the designed primers were custom synthesized from Sigma (Bangalore, India). Semiquantitative RT-PCR was performed in $25 \mu \mathrm{l}$ total volume of reaction mixture, containing $2 \mu \mathrm{l}$ of synthesized cDNA, $1 \mathrm{U}$ of Taq DNA polymerase and $1 \mu \mathrm{l}$ of $100 \mathrm{mM}$ dNTPs, $2.5 \mu \mathrm{l}$ of $10 \mathrm{x}$ buffers and 100 pmol of primers. PCR was carried out in a thermocycler (Labnet, Multigene gradient, California, USA) under the following conditions: Initial denaturation at $94^{\circ} \mathrm{C}$ for 5 min followed by $18-25$ cycles at $94^{\circ} \mathrm{C}$ for $1 \mathrm{~min}$, annealing at $56^{\circ} \mathrm{C}$ for $1 \mathrm{~min}, 72^{\circ} \mathrm{C}$ for $1 \mathrm{~min}$, the final extension at $72^{\circ} \mathrm{C}$ for $10 \mathrm{~min}$.

\begin{tabular}{|l|l|l|l|l|}
\hline Gene & Encoding enzyme & Primers pair Sequence (5'-3') & $\begin{array}{l}\text { Annealing } \\
\text { Temperature }\end{array}$ & $\begin{array}{l}\text { GenBank } \\
\text { accession }\end{array}$ \\
\hline GPOD & Guicol peroxidase & $\begin{array}{l}\text { F: ACCGTGAGCGAGGACTACCT } \\
\text { R: AGCGTCAAGTGAGCCTTAGC }\end{array}$ & $56.0^{\circ} \mathrm{C}$ & KJ748198 \\
\hline$\beta$-actin & Positive control & $\begin{array}{l}\text { F: TGGTCGGAATGGGACAGAAG } \\
\text { R: CTCAGTCAGGAGAACAGGGT }\end{array}$ & $60.0^{\circ} \mathrm{C}$ & - \\
\hline
\end{tabular}

Primed primer sets were designed by primer 3 software and annealing temperature used to amplify GPOD, along with their Gen Bank accession number. $\beta$-actin were synthesized from previous reports.

Table 1: Primers used for RT-PCR assays along with their accession numbers.

Amplified PCR products were purified using QIA quick gel extraction kit (Qiagen, Hilden, Germany) by following the manufacturer's instructions. Amplified products of GPOD were cloned into a pGEM-T Easy vector adding T4 DNA ligase and 1x ligation buffer in $30 \mu \mathrm{l}$ volume. Transformation was carried out using E. coli JM109 by heat shock method. The competent cells were placed on LB plates containing ampicillin incubated overnight at $37^{\circ} \mathrm{C}$. The white transformed clones were confirmed by colony PCR with the same primers. The plasmid DNA was isolated and sequenced commercially (Eurofins, Bangalore, India). The amplified sequence data of enzymes was analyzed by BLAST sequence similarity search and the phylogeny of all genes were constructed with sequence availability in NCBI database.

\section{Total phenol estimation}

Fifteen different eggplant cultivars of seedlings (each $0.5 \mathrm{~g}$ ) were homogenized using $80 \%$ methanol $(\mathrm{w} / \mathrm{v})$ and centrifuged at 10,000 rpm for $10 \mathrm{~min}$. The supernatant was air dried and dissolved in $5 \mathrm{ml}$ of distilled water. The total phenolic content was determined using FolinCioculteou reagent as described by Vanitha, et al. [35] using a standard curve of known concentrations of Gallic acid. The phenolic content was expressed as $\mu \mathrm{g}$ phenol $\mathrm{g}^{-1}$.

\section{Statistical analysis}

Green house experiments and enzyme activities were performed in four replicates and repeated thrice. Data were analyzed by two-way ANOVA (treated and control) using SPSS software. The means were compared for significant effects on enzyme activity by pathogen inoculation by the magnitude of the F-Value $(\mathrm{P} \leq 0.05)$.

\section{Results and Discussion}

\section{Bacterial source and identification}

The bacterial wilt causing pathogen $R$. solanacearum in eggplants were isolated and characterized from infected fields [36]. Isolates of $R$. solanacearum from soil, plant material and seeds were cultured using semi selective media and typical mucoid creamy white colonies with pink centers were observed as reported earlier [23-28] Further different isolates of $R$. solanacearum were further subjected to biochemical/physiological assays along with hypersensitive and pathogenicity tests $[30,36,37]$. These pathogens stained pink red for Gram's reaction and thin viscid mucoid strand for $\mathrm{KOH}$ solubility indicating gram negative nature. $R$. solanacearum indicated negative for gelatin hydrolysis, starch hydrolysis test as well as lipase activity. Kovac's oxidase tests showed a positive result by immediate colour change to blue by $R$. solanacearum. The pathogen changed the color from green to yellow indicating a positive for oxidation test, whereas in 
the fermentation test these pathogens did not shown any reaction. Susceptible tomato and eggplant cultivars when inoculated with $R$. solanacearum isolated from the soil, seed and plant material showed bacterial wilt symptoms such as vascular browning, stunting, wilting and often rapid death of eggplants. Control plants did not show similar disease symptoms. Yellowing of leaf followed by necrosis was evident in tobacco plants within $48 \mathrm{~h}$ of infiltration with both bacterial isolates, whereas control leaves did not show any change in leaf morphology. Biochemical/physiological tests, hypersensitivity and pathogenicity tests were used in the identification and confirmation of the isolated pathogens as $R$. solanacearum. The identity of the phytobacterium was confirmed by amplification of $16 \mathrm{~S}$ rRNA. The $R$. solanacearum isolate has been deposited in the Department Stock Collection Centre (Department of Studies in Biotechnology, University of Mysore) and designated as $R$. solanacearum DOB R1. The amplified sequence of all three regions of phytobacterium has been submitted to NCBI Genbank database with accession number KF021616 [30].

\section{GPOD activity}

The temporal changes of GPOD enzyme activity in R cultivar (Arka Shirish) was gradually increased upon pathogen inoculation and reached its peak at $21 \mathrm{hpi}$. In R cultivar the GPOD enzyme activity was $10.59 \mathrm{U}$ in uninoculated control, which was significantly increased to $42.72 \mathrm{U}$ at 21 hpi upon pathogen inoculation (Figure 1). Meanwhile, the GPOD activity in S cultivar MEBH-11 was $8.9 \mathrm{U}$ in control plants which is gradually increased to 31.52 upon pathogen inoculation. Whereas, in HS cultivar Green Round, the GPOD enzyme activity was $0.4 \mathrm{U}$ in uninoculated control which was increased to $1.5 \mathrm{U}$ hours after pathogen inoculation. Although the activity of antioxidative enzyme GPOD was increased after infection of $R$. solanacearum, the activity of enzyme was rapidly increased in R cultivar Arka Shirish followed by $S$ cultivar MEBH-11 and HS cultivars Green Round in early time intervals of challenge inoculated. Defense-related enzymes GPOD, PPO, PAL, and LOX are known to play a major role biosynthesis of cell wall strengthening material and secretion of antimicrobial compounds such as phytoalexins, furanocoumarin, quinones, and pterocarpan [21] which determine the host resistance. Similar results were exhibited when Cerebroside elicitors initiate accumulation of $\mathrm{H}_{2} \mathrm{O}_{2}$ followed by the production of plant defense-related enzymes viz., PAL, POX, PPO, and LOX in Capsicum annuum L. Similarly, Increase in the GPOD activity was observed during the interaction between tomato and $R$. solanacearum, rice and Xanthomonas oryzae $p v$. oryzae, cotton and Xanthomonas axonopodis pv. malvacearum Cassava bacterial blight caused by Xanthomonas axonopodis pv. manihotis [7-13]. Whereas, similar results were observed in the present study that GPOD play a major role in activation of defense against $R$. solanacearum. A total of three isoforms of GPOD were expressed and its intensity varied between cultivars and even between control and inoculated seedlings. The GPOD isoforms were faint in S and HS seedlings when compared to $\mathrm{R}$ seedlings. There was no difference in number of isoforms in all the three categories of seedlings used which correlated the results of Laemmli and Vanitha, et al. [30,32].

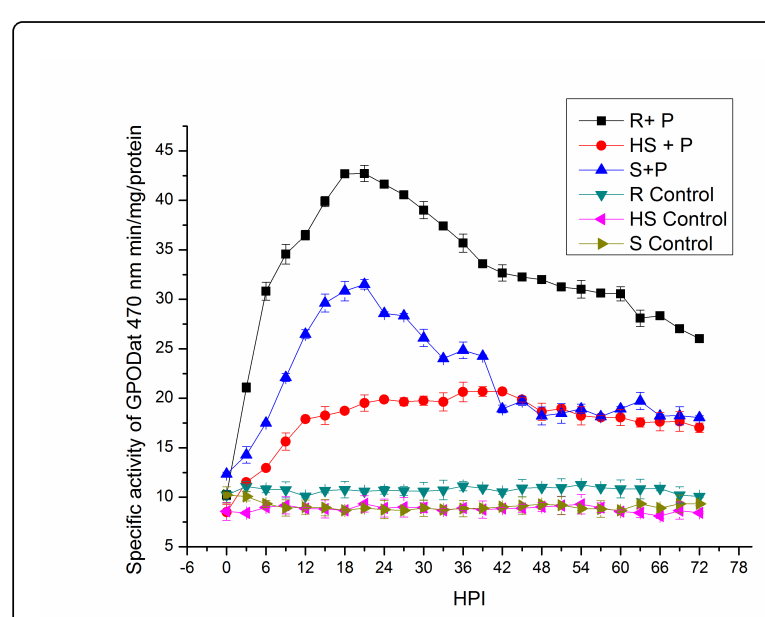

Figure 1: Temporal study pattern of GPOD activity in Resistant (R), Susceptible (S) and Highly Susceptible (HS) eggplant cultivars, Eggplant seedlings were raised from followed by challenge with pathogen. Both treated and control seedlings were harvested at different hours after pathogen inoculation (HPI), and subjected to GPOD enzymatic estimation. The data is expressed as the average of three independent experiments with three replicates. Bars indicate standard errors.

Peroxidase catalyzes the last step in the biosynthesis of lignin and other oxidative phenols. Seed treatment with Lactic acid bacterium $(\mathrm{LAB})$ induced the defense related activities of GPOD. They indicated a significant increase in GPOD activity at $24 \mathrm{hpi}$, observed in the LAB treated seedlings challenge inoculated with $R$. solanacearum suggesting the induction of resistance in tomato plants. The control seedlings reported lowest GPOD activity with or without pathogen infection. However, the seedlings inoculated with Lactic acid bacterium isolate alone also exhibited high GPOD activity in comparison with the control. Similarly, the screened resistant cultivars of eggplant showed similar results when compared to induced resistance in cultivars of tomato against bacterial wilt [38].

\section{RT-PCR studies}

Peroxidase is a defense-related enzymatic gene, with broad spectrum activity and it plays key roles in plant-pathogen interactions. GPOD gene is believed to be one of the most significant factors of the plant's biochemical defense against pathogenic microorganisms, and is actively involved in self-regulation of plant metabolism after infection. Based on the temporal pattern activity of the time intervals for GPOD activity was found to be $18 \mathrm{hpi}$ for both resistant and highly susceptible eggplant cultivars. In GPOD, the gene expression was high in $\mathrm{R}$ cultivars followed by $S$ cultivars and the mRNA transcript accumulation was least in HS cultivars. In order to investigate the role and fold changes of defense genes in protection of ROS caused by bacterial wilt, we have analyzed the activity of GPOD. The GPOD gene expression was significantly increased in R cultivar (Arka Shirish) at 18 hpi and was significantly up-regulated to 5.5 folds upon pathogen inoculation when compared to control (Figure 2) whereas, in S and HS eggplant cultivars, the GPOD gene expression pattern was downregulated to the extent of 0.9 and -3.2 respectively compared to control. A partial amplified cDNA from the eggplant was cloned and 
sequenced commercially, which was later compared with NCBI database using BLASTN algorithm. The GPOD sequences represented homology as cytosolic GPOD isoforms, in which the genes show $100 \%$ homology with GPOD of $S$. melongena. S. tuberosum exhibited $96 \%$ and $98 \%$ homology for GPOD respectively, whereas $95 \%$ and $100 \%$ homology in S. lycopersicum, but less than $90 \%$ was showed with respect to $C$. annuum and $N$. tabacum. The phylogenetic tree constructed using the deduced nucleotide sequences of all the four genes with different genera of Solanaceae species in which genes are conserved across all plant species with slight evolutionary differences between them. The sequences were deposited in the GenBank database of NCBI Accession numbers KX347437.

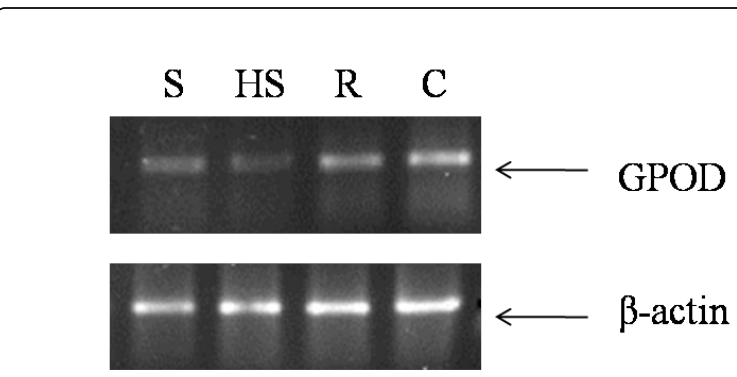

Figure 2: Induced gene expression patterns of defense related enzymes, PR-1a and $\beta$-actin in bacterial wilt pathogenesis of eggplant. A: Amplification of defense enzymes in resistant (R), susceptible (S) and highly Susceptible (HS) cultivars of eggplant seedlings upon pathogen inoculation. After Semi-quantitative RTPCR was carried out, equal volume of $10 \mu \mathrm{l}$ of total DNA was loaded in the gel. The data showed is a one representative example of three independent experiments.

GPOD defense gene plays several important roles in disease resistance expressed against a number of pathogens. Increases in GPOD activity are often associated with progressive incorporation of phenolic compounds within the cell wall during incompatible plantmicrobe interactions or elicitor treatment. In tomato, GPOD is one of the enzymes believed to catalyse the last step in lignifications. The reinforcement of the plant cell wall by phenolics and lignin increases plant resistance to cell wall-degrading enzymes and toxins produced by pathogens, and acts as mechanical barrier to physical penetration of the cell. Increase in GPOD activity in ASM-treated plants may cause oxidative cross-linking of proteins to increase the resistance against bacterial pathogens. Other physiological processes induced as a defense response to pathogens in which GPOD is involved include the deposition of polyphenols and cross-linking of cell wall proteins. Induction of GPOD has been implicated in production of toxic radicals, such as $\mathrm{O}^{2-}$, and $\mathrm{H}_{2} \mathrm{O}_{2}$. In plants, the increased production of both the superoxide radical and $\mathrm{H}_{2} \mathrm{O}_{2}$ is a common feature of defense responses to challenge by avirulent pathogens and elicitors [39]. The expression of GPOD gene in treated plus pathogen-inoculated plants showed a tendency of induction immediately after the infection (0 hpi) with a slight increase of 1.1 -fold, which was then significantly enhanced to 2.1-fold at 24 hpi over the pathogen-infected control alone. In addition, treatment alone resulted in a significant upregulation of GPOD by an 8.5- and 12.3-fold increase at $4 \mathrm{~h}$ and $24 \mathrm{~h}$, respectively, over the SDW-treated control. Similarly, in our present study the fold change in defense expression of GPOD activity was higher in resistant cultivar followed by susceptible and highly susceptible cultivars compared to their respective control.

\section{Total phenol assay}

Rapid increase in total phenolic content at 24 hpi was observed in $\mathrm{R}$ cultivar (Arka Shirish). In $\mathrm{R}$ cultivar the total phenolic content was $87.79 \mu \mathrm{g}$ phenol g-1 in un-inoculated control, which was significantly increased to $236.2 \mu \mathrm{g}$ phenol g-1. The level of total phenolic content was 2.7 folds higher compared to control seedlings. The total phenol content in the S cultivar (MEBH-11) was $80.80 \mu \mathrm{g}$ phenol g-1 in control and was increased to $171 \mu \mathrm{g}$ phenol $\mathrm{g}^{-1}$ when inoculated with pathogen. On the contrary HS which did not exhibit much variation among inoculated and control plants (Figure 3). However, among fifteen cultivars, $\mathrm{R}$ cultivars exhibited the highest phenolic content followed by $\mathrm{S}$ and HS cultivars.

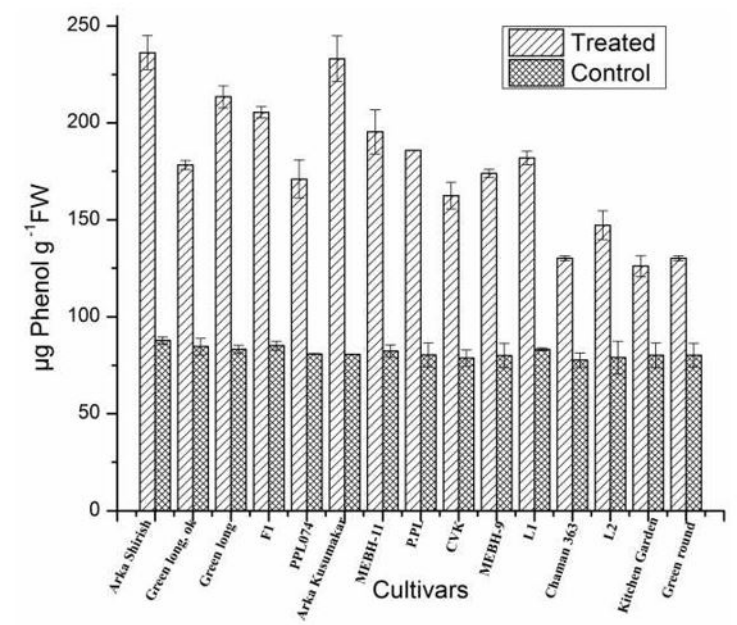

Figure 3: Effect of $R$. solanacearum infection on total phenolic content in different eggplant cultivars at $24 \mathrm{~h}$ with their controls. The values are means of three replicates \pm standard deviation in significance of $\mathrm{P}<0.05$. Bars indicate standard errors.

In our previous reports the activity of phenols was evaluated in the host pathogen interaction of $R$. solanacearum and tomato by Vanitha et al. [32], which revealed the accumulation of phenols with respect to $\mathrm{R}, \mathrm{S}$ and HS cultivars. These antioxidant properties play an important role in quenching ROS by their Redox properties. Phenols and polyphenols are the non-enzymatic antioxidant ROS scavengers which are widely distributed in plant species, which activate defense mechanism. In present study, a significant increase in the levels of phenols and polyphenols was observed after $24 \mathrm{hpi}$ in inoculated plant. Among the 15 cultivars the total phenol content was significantly enhanced upon pathogen inoculation, in which $\mathrm{R}$ cultivar (Arka Shirish) exhibited significant increase in phenols (3 folds) compared to control and least content was observed in MEBH 11 cultivar. The significant difference in phenols and polyphenols were described by Mandal et al. [23] in response of F. oxysporum-tomato, Oidiumneo lycopersici-tomato interaction in susceptible genotypes of tomato. Further, Bean plant response to Bean yellow mosaic virus and Salicylic acid interaction was evaluated with accumulation of total phenols scavenging activity [40]. These results support, that phenols and polyphenolic compounds play an important role in scavenging free radicals with respect to different cultivars of eggplant. Treatment of tomato seedlings with $\mathrm{LAB}$ resulted in high phenol accumulation in plant extracts. Seedlings treatment of $\mathrm{LAB}$ resulted in maximum 
accumulation of phenolics $\left(340 \mu \mathrm{g}^{-1} \mathrm{mg}^{-1}\right.$ catechol) when compared to the control $\left(120 \mu \mathrm{g}^{-1} \mathrm{mg}^{-1}\right.$ catechol). The phenolics accumulation increased after challenge inoculation with $R$. solanacearum and reached the maximum level on $24 \mathrm{~h}$. whereas, similar results were observed in the present study that in resistant cultivar of eggplant accumulation of phenolics was high when treated with pathogen [38].

The general trends of developmental regulation of total phenolics and GPOD in plants were a steady increase with germination and decrees pathogenesis. This is justifiable because higher phenolic synthesis was required for lignifications with growth and defense against pathogenesis. Meanwhile several reports explained GPOD play fundamental roles such as lignifications of cell wall, oxidation of hydroxy-cinnamyl alcohol into free radical intermediates act as potential biochemical marker. The developed novel biochemical and molecular marker play a significant role in screening resistant and susceptible cultivars against bacterial wilt by specific and sensitive increase in activity of GPOD and total phenols in eggplant.

\section{Conclusion}

Our study was an effort to analyze the activity of Guaiacol peroxidase in bacterial wilt pathogenesis of Brinjal. Out of the two cultivars selected, the cultivar- MEBH-9 showed signs of susceptibility to bacterial wilt after pathogen inoculation and the Green variety showed signs of resistance by increase in Guaiacol peroxidase enzyme activity. Simultaneously, there was a significant increase in total phenol in the resistant cultivars with respect to their controls. The developed assay can be used as a Biochemical marker for screening of cultivars against bacterial wilt in Solanum melongena and the developed molecular markers assist for specific, easy and rapid identification of $R$. solanacearum which overcomes the laborious and confusing conventional techniques.

\section{Acknowledgements}

This work was supported by the grants from DBT-MRP [BT/ PR10406/SPD/9/1232/2014], UGC-MRP [36-281/2008 (SR)] and UGC-NONNET fellowship. Authors are grateful to IOE, University of Mysore for spectral characterization and Chairman, DOS in Biotechnology, University of Mysore, Mysore-570006 for their Infrastructure facilities.

\section{References}

1. Adebayo OS, Ekpo EJA (2005) Biovar of Ralstonia solanacearum causing bacterial wilt of tomato in Nigeria. Plant Dis. 89: 1129-1129.

2. Nguyen MT, Ranamukhaarachchi SL (2010) Soil-borne antagonists for biological control of bacterial wilt disease caused by Ralstonia solanacearum in tomato and pepper. Journal of Plant Pathology 92: 395-405.

3. Kumar Naik KH, Ashok B, Naik N, Mulla JAS, Prakasha A (2015) DNA binding, anti-inflammatory and analgesic evaluation of metal complexes of N/S/O donor ligands; Synthesis, spectral characterization, Spectrochim. Acta Part A Mol Biomol Spectrosc 141: 88-93.

4. Ullas B, Chandrashekar P, Suhas R, Rakesh K, Avinash P, et al. (2015) Schiff's bases derived from amino acids- imidazole conjugates as promising antioxidant and antimicrobial agent. Chemistry \& Applied Biochemistry 2 .

5. Schuller DJ, Ban N, Van Huystee RB, McPherson A, Poulos TL (1996) The crystal structure of peanut peroxidase. Structure. 4: 311-321.

6. Hiraga S (2001) A large family of class III plant peroxidases, Plant Cell Physiol. 42: 462-468.
7. Kobayashi K (1996) $\varepsilon$-( $\gamma$-Glutamyl) lysine cross-links of spore coat proteins and transglutaminase activity in Bacillus subtilis. FEMS Microbiol Lett 144: 157-160.

8. Sharma P, Jha AB, Dubey RS, Pessarakli M (2012) Reactive oxygen species, oxidative damage, and antioxidative defense mechanism in plants under stressful conditions. J Bot 2012: 1-26.

9. Southerton SG, Deverall BJ (1990) Changes in phenylalanine ammonialyase and peroxidase activities in wheat cultivars expressing resistance to the leaf-rust fungus. Plant Pathol 39: 223-230.

10. Reimers PJ, Leach JE (1991) Race-specific resistance to Xanthomonas oryzae pv. oryzae conferred by bacterial blight resistance gene Xa-10 in rice (Oryza sativa) involves accumulation of a lignin-like substance in host tissues. Physiol Mol Plant Pathol 38: 39-55.

11. Young SA, Guo A, Guikema JA, White FF, Leach JE (1995) Rice cationic peroxidase accumulates in xylem vessels during incompatible interactions with Xanthomonas oryzae pv oryzae. Plant Physiol 107: 1333-1341.

12. Chittoor JM, Leach JE, White FF (1997) Differential induction of a peroxidase gene family during infection of rice by Xanthomonas oryzae pv. Oryzae. Mol Plant Microbe Interact 10: 861-871.

13. Dai GH, Nicole M, Andary C, Martinez C, Bresson E, et al. (1996) Flavonoids accumulate in cell walls, middle lamellae and callose-rich papillae during an incompatible interaction between Xanthomonas campestri sp V. malvacearum and cotton. Physiol Mol Plant Pathol 49: 285-306.

14. Kpémoua K, Boher B, Nicole M, Calatayud P, Geiger JP (1996) Cytochemistry of defense responses in cassava infected by Xanthomonas campestris pv manihotis. Can J Microbiol 42: 1131-1143.

15. Flood F, Cooper RM, Deshappriya N, Day RC (1995) Resistance of cassava (Manihot esculenta) to Xanthomonas blight in vitro and in plants. In: Physiol. Responses Plants to Pathog. Dundee p: 11-13.

16. Ikegawa T, Mayama S, Nakayashiki H, Kato H (1996) Accumulation of diferulic acid during the hypersensitive response of oat leaves to Puccinia coronata sp. F. avenae and its role in the resistance of oat tissues to cell wall degrading enzymes. Physiol Mol Plant Pathol 48: 245-256.

17. Mohammadi M, Kazemi H (2002) Changes in peroxidase and polyphenol oxidase activities in susceptible and resistant wheat heads inoculated with Fusarium graminearum and induced resistance. Plant Sci 162: 491-498.

18. Shivakumar P, Geetha $\mathrm{H}$, Shetty $\mathrm{H}$ (2003) Peroxidase activity and isozyme analysis of pearl millet seedlings and their implications in downy mildew disease resistance. Plant Sci 164: 85-93.

19. Delannoy E, Jalloul A, Assigbetsé K, Marmey P, Geiger JP, et al. (2003) Activity of class III peroxidases in the defense of cotton to bacterial blight. Mol Plant Microbe Interact 16: 1030-1038.

20. Mlícková K, Luhová L, Lebeda A, Mieslerová B, Pec P (2004) Reactive oxygen species generation and peroxidase activity during Oidium neolycopersici infection on Lycopersicon species. Plant Physiol Biochem 42: 753-761.

21. Silva MC, Guerra-Guimarães L, Loureiro A, Nicole MR (2008) Involvement of peroxidases in the coffee resistance to orange rust (Hemileia vastatrix). Physiol Mol Plant Pathol 72: 29-38.

22. Mika A, Boenisch MJ, Hopff D, Lüthje S (2010) Membrane-bound guaiacol peroxidases from maize (Zea mays L.) roots are regulated by methyl jasmonate, salicylic acid, and pathogen elicitors. J Ex Bot 61: 831841 .

23. Mandal S, Das RK, Mishra S (2011) Differential occurrence of oxidative burst and antioxidative mechanism in compatible and incompatible interactions of Solanum lycopersicum and Ralstonia solanacearum. Plant Physiol Biochem 49: 117-123.

24. Vanitha SC, Umesha S (2011) Pseudomonas fluorescens mediated systemic resistance in tomato is driven through an elevated synthesis of defense enzymes. Biol Plant 55: 317-322.

25. García-Cristobal J, García-Villaraco A, Ramos B, Gutierrez-Mañero J, Lucas JA (2015) Priming of pathogenesis related-proteins and enzymes related to oxidative stress by plant growth promoting rhizobacteria on rice plants upon abiotic and biotic stress challenge. J Plant Physiol 188: 72-79. 
Citation: Prakasha A, Umesha S (2016) Biochemical and Molecular Variations of Guaiacol Peroxidase and Total Phenols in Bacterial Wilt Pathogenesis of Solanum melongena. Biochem Anal Biochem 5: 292. doi:10.4172/2161-1009.1000292

Page 7 of 7

26. Kelman A (1954) The relationship of pathogenicity of Pseudomonas solanacearum to colony appearance in a tetrazolium medium. Phytopathology 44: 693-695.

27. Fahy PC, Fahy PC, Persley GJ (1983) Plant bacterial diseases: A diagnostic guide, Academic Press.

28. Kovacs N (1956) Identification of Pseudomonas pyocyanea by the oxidase reaction. Nature 178: 703

29. Hayward AC (1964) Characteristics of Pseudomonas solanacearum. J Appl Bacteriol 27: 265-277.

30. Avinash P, Umesha S (2013) Identification and genetic diversity of bacterial wilt pathogen in brinjal. Arch Phytopathol Plant Prot 47: 398406.

31. Tans-Kersten J, Huang H, Allen C (2001) Ralstonia solanacearum needs motility for invasive virulence on tomato. J Bacteriol 183: 3597-32605.

32. Naveen J, Hariprasad P, Nayaka SC, Niranjana SR (2013) Cerebroside mediated elicitation of defense response in chilli (Capsicum annuum $L$.) against Colletotrichum capsici infection. J Plant Interact 8: 65-73.

33. Laemmli UK (1970) Cleavage of structural proteins during the assembly of the head of bacteriophage T4. Nature 227: 680-685.

34. Kiirika LM, Stahl F, Wydra K (2013) Phenotypic and molecular characterization of resistance induction by single and combined application of chitosan and silicon in tomato against Ralstonia solanacearum. Physiol Mol Plant Pathol 81: 1-12.
35. Vanitha SC, Niranjana SR, Umesha S (2009) Role of phenylalanine ammonia lyase and polyphenol oxidase in host resistance to bacterial wilt of tomato. J. Phytopathol. 157 (2009) 552-557.

36. Avinash P, Sri USR, Shirin M (2016) Discrimination of Ralstonia solanacearum isolates by genetic signatures produced by single-strand conformation polymorphism and low-stringency single specific primer PCR analysis. African J Microbiol Res 10: 1128-1139.

37. Umesha S, Avinash P (2014) Multiplex PCR for simultaneous identification of Ralstonia solanacearum and Xanthomonas perforans. 3 Biotech 5: 245-252.

38. Konappa NM, Maria M, Uzma F, Krishnamurthy S, Nayaka SC, et al (2016) Lactic acid bacteria mediated induction of defense enzymes to enhance the resistance in tomato against Ralstonia solanacearum causing bacterial wilt. Sci Hortic (Amsterdam) 207: 183-192.

39. Soylu S, Baysal O, Soylu EM (2003) Induction of disease resistance by the plant activator, acibenzolar-S-methyl (ASM), against bacterial canker (Clavibacter michiganensis subsp. michiganensis) in tomato seedlings. Plant Sci 165: 1069-1075.

40. Radwan DEM, Fayez KA, Younis Mahmoud S, Lu G (2010) Modifications of antioxidant activity and protein composition of bean leaf due to bean yellow mosaic virus infection and salicylic acid treatments. Acta Physiol Plant 32: 891-904. 